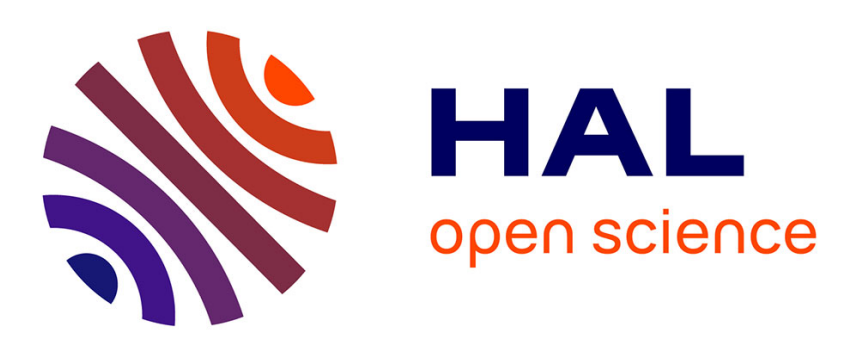

\title{
Can Hybrid Organizations-Based on the Combination of Long-term Employment and Performance-related Pay-Operate Effectively in Japan?
}

\author{
Mitsuharu Miyamoto, Hiroatsu Nohara
}

\section{- To cite this version:}

Mitsuharu Miyamoto, Hiroatsu Nohara. Can Hybrid Organizations-Based on the Combination of Long-term Employment and Performance-related Pay-Operate Effectively in Japan?. Evolutionary and Institutional Economics Review, 2013, 10 (2), pp.217-243. 10.14441/eier.A2013012 . hal02935027

\section{HAL Id: hal-02935027 \\ https://hal.science/hal-02935027}

Submitted on 10 Sep 2020

HAL is a multi-disciplinary open access archive for the deposit and dissemination of scientific research documents, whether they are published or not. The documents may come from teaching and research institutions in France or abroad, or from public or private research centers.
L'archive ouverte pluridisciplinaire HAL, est destinée au dépôt et à la diffusion de documents scientifiques de niveau recherche, publiés ou non, émanant des établissements d'enseignement et de recherche français ou étrangers, des laboratoires publics ou privés. 
Can hybrid organizations-- based on the combination of long-term employment and performance-related pay-- operate effectively in Japan?

Mitsuharu MIYAMOTO: Senshu University, Japan Email:miyamoto@isc.senshu-u.ac.jp Hiroatsu NOHARA: Aix-Marseille University, LEST-CNRS (Institute of Labor Economics and Industrial Sociology), 36 Avenue Jules Ferry, 13616 Aix-en-Provence France

Email: hiroatsu.nohara@univ-amu.fr

This article has been published in:

Miyamoto, M., Nohara, H. Can Hybrid Organizations-Based on the Combination of Long-term Employment and Performance-related Pay—Operate Effectively in Japan?. Evolutionary and Institutional Economics Review, 10, 217-243 (2013). https://doi.org/10.14441/eier.A2013012 


\section{Introduction}

In this article, we investigate the effectiveness of a new type of Japanese firm that introduces performance-related pay (PRP) and maintains long-term employment (LTE) by focusing on the work motivations of employees. After the collapse of the bubble economy at the beginning of the 1990s, and particularly following the outbreak of the domestic banking crisis due to the large amount of bad debts at the end of the 1990s, Japanese firms faced severe hardships, and undertook two types of corporate reform, that is, corporate governance (CG) reform and human resource management (HRM) reform (JILPT, 2007). The former stressed shareholder-oriented CG, and the latter stressed performance-oriented HRM. In fact, the former led to a rapid increase in dividends, and the latter led to the rapid introduction of PRP. From the viewpoint of US-style CG and HRM, both reforms were considered to reduce the prevalence of LTE practice.

However, at least until now, Japanese firms have maintained a policy of LTE for regular workers, although the number of such workers has been reduced significantly by increasing employment of non-regular workers. As a result, a combination of LTE and PRR under shareholder or market-oriented CG emerges as a new type of Japanese firm. Such a combination is said to be a "hybrid" in the sense of being composed of different kinds of institutions, marketoriented CG on one hand, organization-oriented employment on the other, and further, LTE practice on one hand, PRP practice on the other. From these perspectives, Jackson and Miyajima (2007) and Miyajima (2011) classified Japanese firms according to the three items, CG, LTE, and PRP, and found that the hybrid type represented $22.4 \%$ of the 723 firms listed on the Tokyo Stock Exchange First and Second Sections in 2002. They demonstrated six types in total, two other main types among them were a combination of market-oriented CG, and LTE and non-PRP (they accounted for $14.7 \%$ ), and a combination of organization-oriented CG, non-LTE and PRP (they accounted for $21 \%$ ).

Similarly, Miyamoto (2011) classified 1280 firms that have been included in the JILPT survey conducted in 2004 (JILPT 2007), and found that 39.3\% were a hybrid type that was a combination of LTE and PRP, called the new-J type, 18\% were the A type that was a combination of non-LTE and PRP, 29.7\% were the traditional-J type that was a combination of LTE and nonPRP, and $12 \%$ were an in-decline type that was a combination of non-LTE and non-PRP. In particular, it was Miyamoto demonstrated that CG factor such as the introduction of an executive committee system promoted the introduction of PRP and the restriction of LTE on one hand, while 
the CSR factor promoted the maintenance of LTE on the other. Then, it is possible to interpret the diversity of Japanese firms as follows: the new-J (hybrid) type and A type are diversified from the traditional-J type by the effect of the CG factor that introduces PRP, and further, the new-J type and A type are diversified from each other by the effect of the CSR factor that maintains LTE. Such a conjecture corresponds with the view that CG and CSR shape a complementary relationship in CMEs (Jackson and Apostolakou, 2010; Brammer, et al., 2012).

In this way, Japanese firms are moving in different directions, and the new-J (hybrid) type seems to be the most promising in the sense of being representative of large Japanese companies. However, it is not yet clear that hybrid organizations actually work effectively in the Japanese societal context, although a hybrid organization was modeled by Aoki (2010) as the evolving corporate diversity in sophisticated game theory. While hybrid organizations intend to promote employees' work incentives by assuring employment stability on one hand, and by widening wage variations and differentials based on individual performance appraisals on the other, the adoption of a strong PRP scheme, promoted by market-oriented CG, may contradict LTE practice. In particular, in Japanese firms, LTE practice has been understood not only as continuous employment but also as the practice of continuous wage raises on the basis of continuous training for skill formation. In fact, employees have been appraised on a competence rank and promoted on both job and wage ladders (Koike,1988; Marsden,1999). This has had the effect not only to provide wage stability but also to reduce differentials in wages in the short-term, although long-term differentials were widened according to the cumulative competence appraisals. By contrast, PRP intends to widen short-term differentials according to individual performance appraisal. This tends not only to reveal the differentials but also to restrict the opportunities for training and the related employment stability among high performance employees.

When such a strong PRP scheme is adopted, employees' expectation of wage and employment stability with LTE practice may be destroyed. This can be said to be a breach of the psychological contract with existing employees (Rousseau 1995; Hattori, 2011), which may be led to the reduction of employees' motivation for work. Therefore the PRP scheme may be weakened by loosening performance appraisals and constraining wage variations and differentials to become compatible with LTE practice. On the contrary, a new psychological contract may be shaped by employees who expect high wages by achieving high performance according to the PRP scheme. However, such a contract may be destroyed by weakening PRP, which also likely 
reduces the work incentive of employees with the new psychological contract. By facing such a contradiction, a policy that abandons LTE practice and strengthens the PRP scheme to stimulate employees' incentives to a greater extent appears promising. As a result, hybrid organizations may be replaced with the A type organization, a combination of PRP and non-LTE. Alternatively, such restraint of PRP may be a necessary condition for the introduction of PRP to be accepted. In this case, a policy to weaken the PRP scheme seems to be a deliberate choice which makes PRP compatible with LTE. Moreover, PRP itself may be abandoned as a result of disappointment in it. In this case, the hybrid organization returns to the traditional type organization.

From these perspectives, in this article, we examined how PRP operates within hybrid organizations by using two sets of survey data collected by the Japan Institute for Labor Policy and Training (JILPT) in 2005 and 2009. These two surveys provide useful data about employees' work motivation, which could be specified as three types of motivation: achievement of individual performance, contribution to the overall company performance, and meeting the challenge of a new task. As well-known as a multi-task problem (Holmstrom and Milgrom, 1991), PRP focuses on measureable outcomes (such as the achievement of individual performance), and immeasurable outcomes (such as the contribution to the overall company performance and a new challenge) are likely to be neglected. However, as mentioned by Foss and Laursen (2005), there have not been enough studies to test this issue in an empirical manner. Thus, we examined this problem by using employee survey data, and showed that PRP affects these three motivations differently. Finally, we investigated the issue of further diversity among Japanese firms in terms of employee work motivations. Our study was also concerned with the arguments about institutional change in coordinated market economies, specifically about the hybrid type of institutional change (Streeck and Thelen, 2005; Aoki,2010). We were concerned with how the hybrid organization is organized, particularly, how contrasting institutions, LTE and PRP, are compatible with each other.

This article is organized as follows. Section 2 explores previous studies along with PRP literature. Section 3 presents the data that we used and section 4 estimates the effect of PRP on employees' motivations. Section 5 includes a discussion and our conclusions.

\section{Previous studies}

We begins by examining empirical studies to test the effect of PRP on employees' work 
motivation in Japanese firms. Although it is difficult to test directly how employees' motivations change before and after the introduction of PRP, existing studies have examined how employees are motivated by being conscious of wage variations and differentials according to the individual performance appraisals. For instance, Abe (2000) demonstrated a positive relationship between wage differentials and motivation, but also found that employees who did not recognize the differentials were more motivated than those who did. While we saw an interesting implication that recognizing the differentials might affect work motivation negatively, Tsuru (2001) did not find such an effect, and Ota and Otake (2003) found a positive effect on the employees ranked more highly in the wage structure. It seems natural, however, to see higher ranked employees work more regardless of whether PRP is introduced. More importantly, it should be mentioned that work motivations are not necessarily defined well in these studies. They are defined by using statements in questionnaires such as "willing to do overwork", "willing to take work home", and "a strong desire to quit" as proxies for work motivation, or using merely the word "motivation" in general. In contrast, we define motivations by using three different categories as mentioned earlier.

Although the effects of PRP are not necessarily definitive, a large number of studies have examined the effect of PRP as a process. If the process of PRP is conceptualized in such a way that high performance affords high wages (performance $\rightarrow$ wages), high wages induce high motivation (wages $\rightarrow$ motivation), and high motivation attains high performance (wage $\rightarrow$ performance), these processes cannot work effectively when any link is disconnected. In other words, it is necessary to supplement the links in the process to make PRP work effectively. From these perspectives, supplementary conditions that ensure connection of the links have been illuminated; for instance, for the link from performance to wages, the importance of longperspective appraisals, adding competence appraisal, and communication of the appraisal process were pointed out (Morishima, 1999, 2007). Similarly, for the link from wages to performance, the importance of clarifying work objectives, agreement on goal setting, and opportunities for training were pointed out (Genda et al., 2001; Otake and Karasawa, 2003). It is certainly true that these conditions are important because PRP has been criticized for deteriorating into short-termism and over-estimation of outcomes as soon as it was introduced. However, they are not only important for the effectiveness of PRP, but important similarly for the organization to achieve good performance regardless of whether PRP is introduced. As Marsden (2009) mentioned, the 
significance of PRP lies in providing the recognition that those conditions such as communication for goal setting are needed for effective work performance within organizations.

However, a link remains in the PRP process, from wages to motivation. In this regard, two influential arguments exist against the effectiveness of PRP from opposite perspectives. One suggests that PRP is not effective because work motivation depends intrinsically not on monetary incentives but on the significance of and satisfaction with the work (Takahashi, 2004). The other suggests that PRP is not effective because monetary incentives are not enough (Joho,2004). This insists that wage variations and differentials are small despite the belief that they were widened by the introduction of PRP, so they fail to stimulate employees' incentive. For instance, one argument has demonstrated that wage differentials were small even in the organization that introduced PRP because of the concentration of appraisals on the average rating (Nakajima et al., 2004). This is because line managers bear the stress associated with giving a low performance rating to their subordinates, which is likely to be more striking in the organization where the longlasting relationships of co-workers are continued by the LTE policy. In addition, supplementary conditions for PRP working, such as long-perspective appraisal and adding competence appraisal, result in the restraint of wage variations and differentials. As mentioned in the introduction, this is a case where the psychological contract followed by the PRP scheme is destroyed.

In this regard, we can present two kinds of data on wage differentials from the JILPT firm survey that we used to demonstrate the diversity of Japanese firms as described in the introduction (JILPT, 2007). One is wage differentials between firms that introduced PRP (denoted as PRP firms) and firms that did not (denoted as N-PRP firms) as shown in Figure1. The other is the wage differentials between the new-J type that introduced PRP and maintained LTE and the A type that introduced PRP and did not maintain LTE as shown in Figure 2. Here the wage differentials are measured as the range between the maximum and minimum wage paid to section managers by the average being fixed as 100 , and they are also measured by distinguishing between the ex-ante and ex-post differentials, the former being the designed differentials on the wage table and the latter being the actually paid differentials.

Insert Figure 1 here

Insert Figure 2 here 
As shown in Figure 1, while the ex-ante differentials are designed to be in the range of 40, the range is reduced to 27 for ex-post differentials (33\% reduction) even in the PRP firms, and interestingly, the ex-post differentials in the PRP firms are nearly equal to the ex-ante differentials in the N-PRP firms. In other words, while wage differentials are designed even in the traditional organizations that did not introduce PRP, such differentials are not realized, rather they are realized by introducing PRP with reduced scale.

More interestingly, Figure 2 shows that even though the ex-ante differentials are roughly the same between the new-J type and A type, ex-post differentials are reduced more in the new-J type than the A type. This suggests that the PRP scheme is likely to be weakened more in the firms that maintain the LTE.

From these findings, we can conclude that, first, the working of PRP is restrained in Japanese firms, and secondly, it is even more restrained in hybrid firms . One perspective is that such a weakened PRP may fail to motivate employees' incentives to work, and these firms will change their structure to the strengthened PRP by discarding the LTE, or they will return to the traditional structure by discarding the PRP. In fact, there were debates about the advantages and disadvantages of PRP in the media when PRP was introduced around 2000. Now such debates are rarely heard: for instance, the number of articles in the Nikkei newspaper discussing PRP increased from 136 in 2000 to 256 in 2004, but fell to 56 in 2010, amongst which there were considerable numbers of articles reporting the abandonment of PRP. This may be a result of a decline in interest in PRP, which may in turn reflect a decline in the effectiveness of PRP because of the modification of PRP for restraint. In contrast, another perspective is that such a weakened PRP may be a supplementary condition for the PRP process to operate effectively under the LTE policy. This suggests that the recent lower number of articles reflect that PRP has become acceptable by its modification.

From these perspectives, we examine the effectiveness of hybrid organizations in terms of employees' work motivations. In particular, we investigate the PRP scheme that wage variations and differentials are widened by the introduction of PRP in order to stimulate employees' work incentives. This is done by examining three motivations, motivation for achieving individual performance, contributing to the overall company performance, and meeting the challenge of a new task. 


\section{Data}

This section presents the two data sets from the JILPT surveys and provides the related variables for the regression analysis in the next section. These surveys were conducted four times by JILPT as firm surveys in 2004 and 2008, and employee surveys in 2005 and 2009. The data from the two employee surveys are used here. The 2005 employee survey aimed at examining how employees viewed changes in CG and HRM. This was done in accordance with the 2004 firm survey, which aimed at examining how Japanese firms changed CG and HRM practices under conditions of economic hardship after the banking crisis at the end of the 1990s. The 2005 employee survey was conducted by sending a questionnaire to employees in 1280 firms, which had been respondents to the 2004 firm survey, and 2823 replies were obtained from employees in 239 firms. The data from the 2004 firm survey were used for the previous description such as the four types of Japanese firms, ex-ante and ex-post wage differentials. The second employee survey in 2009 aimed at examining how employees viewed changes in CG and HRM practices under the rapid recovery of the Japanese economy from 2003 to 2007. This was done in accordance with the 2008 firm survey that aimed at examining how CG and HRM practices changed during that recovery. The second employee survey was conducted by online, and 12,000 replies were obtained. Among them 1457 employees belonged to public or nonprofit organizations, and they were excluded from the following analysis. Similarly, 3089 employees in the 2009 survey who worked for firms with fewer than 100 employees were excluded, whereas all respondents in the 2005 survey worked for firms with more than 100 employees. Furthermore, several executives included in the 2005 survey were excluded, and employees over 60 years old were also excluded in both surveys. Thus, the final numbers of respondents was 2802 in the 2005 survey, and 8353 in the 2009 survey.

The characteristics of the respondents in both employee surveys are presented in Table 1. As the respondents working for firms with less than 100 employees and for public and nonprofit organizations were excluded in the 2009 survey, the proportion belonging to firms with over 1000 employees is more than half. As the 2009 survey was conducted by online and designed to equalize the number of respondents for each post, the proportion of division and section managers was larger than in the 2005 survey, and similarly, the proportion of older workers was larger in the 2009 survey than in the 2005 survey. Web surveys sometimes have questionable reliability, and there may be bias in the 2005 survey because the respondents are from 239 firms, 
11 employees on average per firm, meaning that similar responses may be obtained from a particular firm. Below we check the validity of our results by comparing the results from the two data sets.

Insert Table 1 here

As for the employees' motivation for work, we could use responses to the following three statements: "I became more conscious of achieving my task", "I became more conscious of the overall company performance", and "I became more conscious of the challenge of doing a new task". We matched these responses with the three kinds of motivation: motivation for the achievement of individual performance, for the contribution to overall company performance, and for the meeting the challenge of a new task. The responses were scored on a five-point scale, where "yes" and "yes a little" responses were combined into "increase" for motivation, "almost none" and "none" were combined into "decrease" for motivation, and "neither yes nor no" was assumed as "no change" for motivation. Table 2 shows the percentage of these three responses by distinguishing two groups: one is those who replied there was PRP introduction at their work place (denoted as PRP employee), and the others who did not (denoted as N-PRP employee).

Insert Table 2 here

These data shows that, first, regarding the employees who were aware of PRP, more than half responded with "increase" for the motivation for both individual performance and overall company performance, whereas only one-third responded with "increase" for the motivation for meeting a new challenge in the 2005 survey. Second, by comparing the two employee groups, PRP and N-PRP, more in the former responded with "increase" than the latter for individual performance, whereas both responded in equal percentages for overall company performance and meeting a new challenge. Third, fewer "increase" responses were recorded in 2009 compared with 2005 for all motivations.

In this regard, as shown in Figure3, we see the average score of each motivation (increase $=3$, no change $=2$, decrease $=1$ ) for the two groups. This shows that, first, motivation for the overall company performance is relatively high regardless of awareness of PRP. If such a 
motivation is regarded as the employees' organizational commitment, Japanese employees are still likely to be organizationally minded. Furthermore, we confirmed that each motivation is significantly lower in the 2009 survey than in the 2005 survey. Although we should be careful in concluding a declining motivation from these results because there is no correspondence between the two sample populations, they suggest that PRP is unlikely to motivate employees' work incentive. However, such results are also observed in the employees who were unaware of the introduction of PRP. In short, work motivation seems to be declining regardless of PRP. Although it is beyond the scope of this article to discuss the reason for this, deterioration in conditions in the workplace environment has been mentioned such as increased work stress, decreased time available for training, and weakened cooperative atmosphere (JILPT, 2007).

Insert Figure3 here

To estimate the determinants of the three specified motivations, we summarized our statistical treatment of the independent variable in Table 5. First, we examined employee awareness of LTE and PRP. In 2005, 41\% of the respondents, and in 2009, 44\% of them thought that LTE would be maintained in their companies, and 63\% in 2005 and $71 \%$ in 2009 thought that PRP had been introduced in their companies. The high percentage in the 2009 survey who thought PRP had been introduced was likely to reflect the large number of firms with more than 1000 employees in the sample. This table also shows the percentage of firms that replied they maintained LTE and introduced PRP in the third column, based on the 2004 firm survey. They were derived from the four types of Japanese firms described in the introduction: the percentage of firms that maintained LTE is $69 \%$ as the sum of the new-J and traditional types, the percentage of firms that introduced PRP is $57.3 \%$ as the sum of the new-J and A types. As mentioned above, the 2005 employee survey corresponded with the 2004 firms survey, and it was demonstrated that there is a large perception gap between firms and employees about LTE; while $70 \%$ of firms intended to continue the LTE practice, only $40 \%$ of the employees expected it to be continued. In contrast, the perception gap is small about PRP: 57\% among firms intended to continue the PRP practice and $63 \%$ among employees expect it to continue. Although we do not discuss the large perception gap about the LTP policy in detail, it is important to examine how the expectation of LTE affects employees' motivations. 
Insert Table 3 here

Second, regarding wage variations, we asked how wages including bonuses were composed, and how wages varied according to performance appraisals. Performance-based wages accounted for only $30 \%$ of total wages even for employees who were conscious of PRP introduction, although the variance was large, from $0 \%$ to $100 \%$. We examined whether the motivations were promoted by raising the proportion of performance pay. As for the wage variation, we asked how wage increased or decreased according to the appraisals of work results by setting the regular wage at the 100 level. Average ranges between wages for good and poor results are shown; wages increased by $10 \%$ on average for good achievements and decreased $10 \%$ for poor achievements, although the variance was also large. We also examined whether the motivations were promoted by an increase in the variation.

Third, as for the wage differentials, we distinguished two kinds of wage gaps: horizontal differentials between employees with similar tenures and vertical differentials between employees with different tenures, and asked whether the two differentials widened or contracted. Of the employees who were conscious of PRP introduction, 43\% in 2005 and 31\% in 2009 perceived that horizontal differentials were widening, very few perceived them to be contracting in both surveys. In contrast, about one-quarter of the employees in both surveys perceived that the vertical differentials were widening, whereas $24 \%$ in 2005 and $11 \%$ in 2009 perceived them to be contracting. Here, we considered that horizontal differentials were a result of the differentials in pay rise generated by a promotion gap within the same cohort by short-term performance appraisals. Similarly, we considered that vertical differentials were a result of the promotion gap by long-term performance appraisals. The latter is also regarded as the slope of the wage curve. As mentioned by Tsuru et al.(2005), the short-term promotion gap widened following the introduction of performance appraisals, and the wage curve flattened following the introduction of PRP. We examined whether the motivations were promoted by recognition of these differentials.

Finally, we asked how satisfied employees were with their work contents. About half were satisfied (this included replies of a little satisfied), about $30 \%$ were neither satisfied nor dissatisfied, and about 20\% were dissatisfied (this included replies of a little dissatisfied). We examined whether work satisfaction was more important than monetary incentives to motivate employees to work. 


\section{Estimation}

In this way, we could estimate the effect of PRP on employees' work motivations. The dependent variables were the three kinds of motivation; motivation for individual performance, overall company performance, and challenge of a new task. Ordered logit analysis was applied by scoring them as increase $=3$, no change $=2$, decrease $=1$. The independent variables were: 1 ) PRP dummy (survey reply of introduction $=1$, otherwise $=0$ ); 2) proportion of performance pay to total wage; 3) wage variations between good and poor result; 4) square of variations; 5) horizontal differentials, widening dummy and contracting dummy; 6) vertical differentials, widening dummy and contracting dummy; 7) LTE dummy (survey reply of maintaining $=1$, otherwise $=0$ ); 8) cross dummy between PRP and LTE dummies; and 9) degree of satisfaction of work content (five-point scoring; satisfied $=5$, a little satisfied $=4$, neither satisfied nor dissatisfied $=3$, a little dissatisfied $=2$, dissatisfied $=1$ ).

A cross dummy between PRP and LTE was introduced to test the effect of the hybrid organization. Work satisfaction was introduced to test the argument that work content or significance rather than monetary incentives motivates employees more effectively. The control variables were; 1 ) post dummy (division and section managers $=1$, otherwise $=0$ ); 2) tenure: 3 ) size dummy (firms with more than $1000=1$, otherwise $=0$ ): and 4) industry dummy (manufacturing $=1$, otherwise $=0$ ). The control variables were categorized in a wide range because their distributions vary significantly between the 2005 and 2009 surveys.

The results are predicted as follows. 1) As for the wage effects of the PRP scheme, employees who recognize PRP introduction, and perceive an increase in the proportion of performance pay and widening wage variation are more motivated for work. 2) When the coefficient of the square of wage variations is negative, the variation effect will decrease beyond a certain level. 3) For the horizontal differentials, it is supposed that employees who recognize them to be widening perceive short-term performance appraisals to be strengthened, then they are more motivated in the PRP scheme. In contrast, for the vertical differentials, employees who recognize them to be widening perceive long-term performance appraisals to be strengthened, thus they are less motivated in the PRP scheme. The latter is also interpreted to mean that those employees perceive the wage curve to be more seniority-based; then they are less motivated. Thus, the widening dummy will be positive and the contracting dummy will be negative for the horizontal differentials, whereas the widening dummy will be negative and the contracting 
dummy will be positive for the vertical differentials. 4) The LTE dummy and cross dummy between PRP and LTE will be positive if the hybrid organization is effective. 5) For work satisfaction, as long as the work effect is positive, it is assumed to surpass or substitute for the wage effect.

As shown in Table 5, variables of the proportion of performance pay and wage variations in the 2009 survey were available only for the employees who replied that PRP had been introduced. Then, the estimation was carried out by distinguishing between two cases: one includes all employees, and the other is restricted to employees with a PRP reply. The former estimation tested the effect of the recognition of PRP, and the effect of the recognition of both PRP and LTE as a hybrid effect. The latter estimation tested the wage effects such as the proportion of performance pay and wage variations, and the wage structure effects such as the horizontal and vertical differentials for employees who recognize PRP introduction. These estimations were carried out on the three motivations, separately.

Table4 shows the estimation results for the effects on motivation for achieving individual performance. Estimations (1) and (2) in 2005 and 2009 include all employees, whereas estimations (3) and (4) in 2005 and 2009 are limited to the employees who recognize PRP introduction. The results in the 2005 estimation are as expected. First, as shown in estimations (1) and (2), being conscious of the introduction of PRP and conscious of both PRP and LTE as a hybrid organization have a positive effect. Second, as shown in estimations (3) and (4), being conscious of the larger proportion of performance pay, and conscious of the larger wage variation have positive effects under the awareness of PRP. The coefficient of the square of variations is negative as expected, and the effects of horizontal and vertical differentials are also as expected; the widening dummy of the horizontal differentials and the contracting dummy of the vertical differentials show a positive effect for employees who recognize the PRP scheme. It is also observed that the coefficients of the wage effects, the proportion of performance pay and the wage variations, are smaller in the 2009 estimation than in the 2005 estimation. Thus, it seems the effect of PRP is declining. This is confirmed by estimating the marginal effects of these variables on the probability of the increased response for work motivation. Estimation results are shown in the lower table in Table 4, where the marginal effect of each variable declines more in 2009 compared to 2005. Furthermore, estimation (4) in 2005 and 2009 demonstrates the important observation that the LTE dummy becomes insignificant when the effect of work satisfaction is considered. As 
mentioned below, the effect of LTE seems to be replaced by the work effect. Finally, the four estimations, in 2005 and 2009, show the same results although the two sample populations are quite different. In this sense, our estimations can be regarded as robust.

Insert Table 4 here

Table5 shows the estimation results for the effects on motivation for contributing to the overall company performance. It is observed, first, the PRP dummy is not significant in both the 2005 and 2009 estimations. In contrast, the effect of awareness of the larger proportion of performance pay, of the larger wage variation, and the widening dummy of the horizontal differentials show a positive significance. This implies that although the wage effects are functioning, this does not relate to the PRP scheme. Here we see a so-called multi-task problem: as PRP emphasizes measurable performance, motivation for immeasurable performance items such as the individual contribution to the overall company performance is likely to be neglected. In contrast, the cross dummy between PRP and LTE is positive both in the 2005 and 2009 estimations, that is, hybrid organizations work effectively to motivate employees for the overall company performance. The coefficient of wage variations is also smaller in 2009 than in 2005, and the effect of the proportion of performance pay is insignificant in the 2009 estimation. In this sense, the wage effects seem to be in decline although these have nothing to do with the PRP scheme. This is also confirmed in terms of the estimation of the marginal effects as shown in the lower table in Table 5.

Insert Table 5 here

Table 6 shows the estimation results for the effects on motivation for meeting the challenge of a new task. As in the estimation for overall company performance, the PRP dummy is not significant in the 2009 estimation, whereas it is significant in the 2005 estimation, but at the 10 percent level and very weak. In contrast, the cross dummy is significant, indicating that hybrid organizations work effectively. In addition, it is observed that the wage effects are very restrictive; significant effects are observed only in the proportion of performance pay in the 2005 estimation, and in the wage variations in the 2009 estimation. Furthermore, as for the effect of the 
horizontal differentials, the contracting dummy is effective in 2009 , whereas the widening dummy is effective in 2005. Although the two are opposite, the former effect implies that the motivation for a new challenge is promoted by constraining the short-term performance appraisals among the same cohort. These results also seem to support the argument that as PRP emphasizes the appraisals of the actual results, motivation for accepting the challenge of a new task is likely to be dampened because the prospects of successful achievement are uncertain.

\section{Insert Table 6 here}

Finally, as seen in estimation (4) in 2005 and 2009, in Tables 6 - 8, work satisfaction has a positive effect on the three motivations consistently. Its effectiveness is also found in the value of coefficient of estimate determination, which rises conspicuously by adding the work effect. More interestingly, by comparing estimation (3) with estimation (4) in 2005 and in 2009, the wage effect is not affected by the work effect. In short, the work effect and wage effect are compatible in motivating employees to work. Furthermore, as for the motivation for individual performance, the effect of LTE disappears by adding the work effect. This suggests that even if the LTE effect is lost by the abandonment of LTE policy, the work effect will compensate for it regarding the motivation for individual performance. In contrast, concerning company performance and new challenges, the work effect and LTE effect consistently raise motivations.

These results do not change even by including the effect of occupations. Although the description of the estimation results was omitted here, we looked at the effects of occupation dummies, such as administration, sales, R\&D, and marketing sections, and observed that the administration dummy has a negative effect and the sales dummy has a positive effect on individual performance, the sales and marketing dummies have positive effects on company performance, and the marketing dummy has a positive effect on meeting a new challenge. Although the R\&D dummy is not significant for any motivations, other results are plausible. For instance, administration is difficult to appraise in terms of individual performance, and in contrast, it is interesting to see that the marketing dummy, including the product development section as well as the sales section, has a positive effect on motivation for both company performance and a new challenge. 


\section{Concluding discussion}

The purpose of this article was to investigate whether the new workplace structure in Japanese firms is operating effectively. This new direction, represented by the new-J type (hybrid type) firms, is aimed at promoting employees' work motivation by introducing PRP in combination with the existing LTE policy. However, this may restrain the effect of PRP by limiting the degree of wage variations and differentials. Then, the other direction, represented by the A type firms, may be adopted by strengthening PRP and abandoning LTE. From these points of view, we estimated the effects of PRP on employees' motivations by defining three types of motivation: motivation for individual performance, for overall company performance, and for a new challenge.

In summary, first, we observed that PRP affected employees' motivations differently. Regarding the motivation for individual performance, the PRP scheme was confirmed to work effectively. As for wage effects of raising the proportion of performance pay and widening wage variation, and wage structure effects of widening the horizontal differentials and contracting the vertical differentials, all functioned as expected following the introduction of PRP.

However, regarding the motivation for overall company performance, while wage effects were observed, introduction of PRP had no significant effect. Although wage effects are significant, they are separated from the PRP scheme. This was also observed regarding the motivation for a new challenge, and wage effects were restricted to a bigger extent. Then, we concluded that PRP scheme was effective only on employees' motivation for achieving individual performance. This has been argued as a multi-task problem (Holmstrom and Milgrom,1991), although empirical evidence has not necessarily been provided (Foss and Laursen, 2005). We could examine this empirically by specifying work motivation for measurable performance item such as achieving an individual performance, and immeasurable performance item such as contributing to the overall company performance and meeting a new challenge. In contrast, we confirmed that the cross dummy between PRP and LTE as a hybrid effect has a positive effect on the three motivations consistently.

Second, it was confirmed that the effect of wage variations had an upper limit, and decreased beyond a certain level. This was demonstrated concerning the motivation for individual performance as seen in Figure 4, where two curves are simulated in the form of the equation $\mathrm{Y}=$ $a_{1}+a_{2} X+a_{3} X^{2}$, where $Y$ is the probability of increasing motivation for individual performance, $\mathrm{X}$ is the range of wage variation by $\log$ transformation, $\mathrm{a}_{2}$ is the coefficient of wage variation, and 
$a_{3}$ is the coefficient of the square of variations in estimation (3) in 2005 and 2009. It is understood that the effect of wage variations decreased rapidly in the 2005 estimation, and the effect was significantly smaller in the 2009 estimation than in the 2005 estimation. The range of wage variation that corresponds with the upper limit is 8 in the 2005 estimation, and 20 in the 2009 estimation. In contrast, as shown in Table 3, medium range of wage variation that employees perceive is 15 in the 2005 survey, and 20 in the 2009 survey. Then, the wage range in 2005 was excessive in most cases. In this sense, it seems reasonable to limit the wage variation even in the PRP scheme.

Insert Figure 3 here

Third, contrary to the argument that it is work satisfaction rather than monetary incentives that motivate employees, we observed that the work effect and wage effect were compatible for promoting employees' three motivations. On the contrary, it was observed that the work effect replaced the LTE effect regarding the motivation for individual performance. This suggests that even if the LTE policy was abandoned, and the LTE effect disappeared, it is compensated for by the work effect at least for individual performance.

From these findings, we are able to predict that Japanese firms will be further diversified. One possibility is to require employees to focus only on achieving individual performance, and thereby strengthen the PRP scheme. This may be a resolution of the multi-task problem by rearrangement of the organization in accordance with the PRP scheme. Even if the LTE policy is abandoned to strengthen the PRP scheme, the work effect will compensate for the LTE effect insofar as work satisfaction can be realized. In this way, we might see the number of A type firms increasing. One large Japanese securities company is said to be headed in this direction that strengthens PRP without job security for specific new employees. Generally, in the field of modular type organizations, jobs are defined separately from each other and from the entire organization, the multi-task problem is easily resolved by assigning employees to a specific job. As seen in the findings of Jackson and Miyajima (2007), the inverse hybrid type, a combination of PRP and non-LTE, is found in the ITC and service sectors in which modular type organizations are likely to be prevailing. However, these A type or inverse hybrid type firms have to be able to raise work satisfaction for strengthening the PRP scheme to work effectively. 
In contrast, it is also appropriate to maintain the LTE and restrain the PRP scheme if employees are required to be more conscious of overall company performance and meeting the challenge of a new task. The LTE effect and work effect are maximized in the motivation for a new challenge. As mentioned above, if firms' concerns with PRP are declining, this may not only be due to the decline of the effect of PRP, but also due to a change in firms' concern, from enhancing the achievement of individual performance to promoting employees' awareness of overall company performance and new challenges. At the time of first introducing PRP, individual performance was the primary focus, but thereafter, the shortcomings of focusing only on individual performance were recognized, and that resulted in modification of the PRP scheme. Our research in this article provides an empirical explanation to these processes.

Such a direction, with the new-J type and hybrid type firms, is more commonly found in the manufacturing sector as seen in the findings of Jackson and Miyajima (2007). Generally, in the field of integral type organizations, jobs are not separable from each other and not separable from the entire organization, and moreover, competitiveness depends on organizational competence for the firm's various activities. Such organizations seem to require greater concerns with overall company performance and new challenges on the side of employees. In this regard, we note an interesting case study presented by Olcott(2009), which investigated how Nissan employees recognized the changes in CG and HRM generated by the merger with Renault. Olcott found that Nissan employees were aware of very large changes in CG, but they perceived small changes in wages and employment. In particular, while Nissan employees recognized there was a greater request to achieve individual performance by the introduction of PRP, they did not perceive a large change in the actual wages. This seems to be consistent with our conclusion, the weakened PRP in the hybrid organization. Of course, achieving individual performance should not be neglected even in the hybrid organization. However, the effect of wage variations is restricted and appears to be declining. In contrast, the hybrid dummy shows a positive effect consistently with respect to individual performance. In this sense, it is not beneficial for the hybrid organization to widen wage variations and differentials according to the PRP scheme. A more important problem for the hybrid organizations is in the perception gap about the LTE policy. The fact that less than half of all employees acknowledge the continuity of LTE policy may become a critical issue for Japanese firms. To investigate the reasons for this gap and the results from it will be the next topic of our research. 


\section{Acknowledgements}

We wish to thank Tsuyoshi Tsuru (Hitotubashi University), Katsuyuki Kubo (Waseda University), Setsuo Yamada (Senshu University), Osamu Umezaki (Hosei University) for their valuable suggestions and comments. This article results from the research project NewDynam funded by ANR (the French Agence National de recherché) et JSPS (Japan Society for the Promotion of Science).

\section{References}

Abe, M (2000), "Internal Wage Differentials and Work Incentives", Economic Studies, (Hitotsubashi University), 51.2: 111-123.

Aoki, M.(2010), Corporations in Evolving Diversity, Oxford University Press, Oxford.

Brammer, S.,G. Jackson, D. Matten (2012),” Corporate Social Responsibility and Institutional Theory: New Perspectives on Private Governance". Socio-Economic Review, 10.1, 3-28.

Foss, N. and K. Laurse. (2005), "Performance Pay, Delegation and Multitasking under Uncertainty and Innovativeness: An Empirical Investigation”, Journal of Economic Behavior and Organization, 58, 246-276.

Genda, U., R. Kanbayashi, and T. Shinozaki (2001), "Performance Pay and Competence Development: Work Motivation as a Result",_Organization Studies, 34.3: 18-31.

Hattori, Y. (2011), Psychological Contract in Japanese Companies, Hakuto-shobo, Tokyo.

Holmstrom, B. and P. Milgrom (1991), "Multi-task Principal-Agent Analyses: Incentive Contracts, Asset Ownership, and Job Design”, Journal of Law, Economics, and Organization, 7: 24-52.

Jackson, G. and A. Apostolakou (2010), "Corporate Social Responsibility in Western Europe: An Institutional Mirror or Substitute?" Journal of Business Ethics, 94.3, 371-394.

Jackson G. and H. Miyajima (2007),'Introduction: The Diversity and Change of Corporate Governance in Japan”, In M. Aoki., G. Jackson., H. Miyajima, (eds.). Corporate Governance in Japan, Oxford University Press, Oxford, pp.1-47.

JILPT (2007), Japanese Company and Employment: Whither the Long-term Employment and Performance-related Pay, Japan Institute of Labor Policy and Training, Tokyo.

Joho, S. (2004), Decline of Performance Pay from the Inside View of Fijitsu, Kobunsha, Tokyo. 
Koike, K. (1988), Understanding industrial relations in modern Japan, translated by M. Sako, Basingstoke, Macmillan.

Marsden, D. (1999), A theory of Employment Systems: Micro-foundations of Societal Diversity, Oxford University Press, Oxford.

Marsden, D. (2009) “The paradox of performance related pay system: Why do we keep adopting them in the face of evidence that they fail to motivate?" CEP Discussion Papers, No.946. Centre for Economic Performance, London School of Economics and Political Science, London.

Miyajima, H., (2011) "How Understand the Changes in the Japanese Corporate Governance", In H. Miyajima (ed.) Japanese Corporate Governance, Toyokeizai-shinposha, Tokyo, pp.1-70.

Miyamoto, M. (2011), "Whither the Japanese employment and corporate governance", In H. Sakurai, et al.(eds.), Japanese Economy toward the Untraded Age, Soseisha, Tokyo, pp.57-126.

Morishima, M., (1999), "The Effects of Performance Pay on the Workplace", Journal of Japan Labor Studies, 472: 2-14.

Morishima, M., (2007), "Current State and Issues of the Appraisals and Human Resource Treatment", In JILPT (ed.), Japanese Company and Employment: Whither the Long-term Employment and Performance-related Pay, Japan Institute of Labor Policy and Training, Tokyo, pp.135-182.

Nohara, H., (1995), "Les salaires en France et au Japon. Comparaison des structures de salaires dans l'industrie manufacturière des deux pays de 1978 à 1986", Travail et Emploi, 62: 59-71.

Nohara H., (1999), "Human Resource Management in Japanese Firms Undergoing Transition: A Hierarchical Approach”. In: Dirks D., Huchet JF., Ribault T. (eds) Japanese Management in the Low Growth Era. Springer, Berlin, Heidelberg.

Nakajima, T., Matsuzaki, J, and Umezaki, O.(2004), "The Effect of Performance Related Pay on the Wages and Appraisals", Japan Economic Studies, 48: 18-33.

Ota, S. and Otake, F. (2003), "Growth of Firms and Work Incentives", Financial Review, Bank of Japan, 67: 4-34.

Olcott, G. (2009),_Conflict and Change: Foreign Ownership and the Japanese Firm,_Cambridge University Press, Cambridge.

Otake, F. and H. Karasawa (2003), "Performance Related Pay and Work Motivations", Economic Studies (Hitotsubashi University), 54.3: 193-205

Rousseau, D. (1995), Psychological Contract in Organization: Understanding Written and Unwritten Agreements, SAGE Publications, London. 
Streeck,W. and K. Thelen. (2005),"Introduction: Institutional Change in Advanced Political Economies", in W. Streeck and K.Thelen (eds.) Beyond Continuity. Oxford University Press, Oxford, pp.1-39.

Takahashi, S.,(1999), Performance-related Pay, Toyokeizai-shinposha, Tokyo,

Takahashi, N.,(2004), Falseness of Performance-related Pay, Nikkei BP-sha, Tokyo.

Tsuru,T.(2001), "The Responses of Employees to Personnel Appraisals and Wage Differentials", Economic Studies (Hitotsubashi University), 52.2: 143-156

Tsuru, T., M.Abe, and K. Kubo (2005), Human Resource Management Reform in Japanese firms, Toyokeizai-Shiposha, Tokyo. 


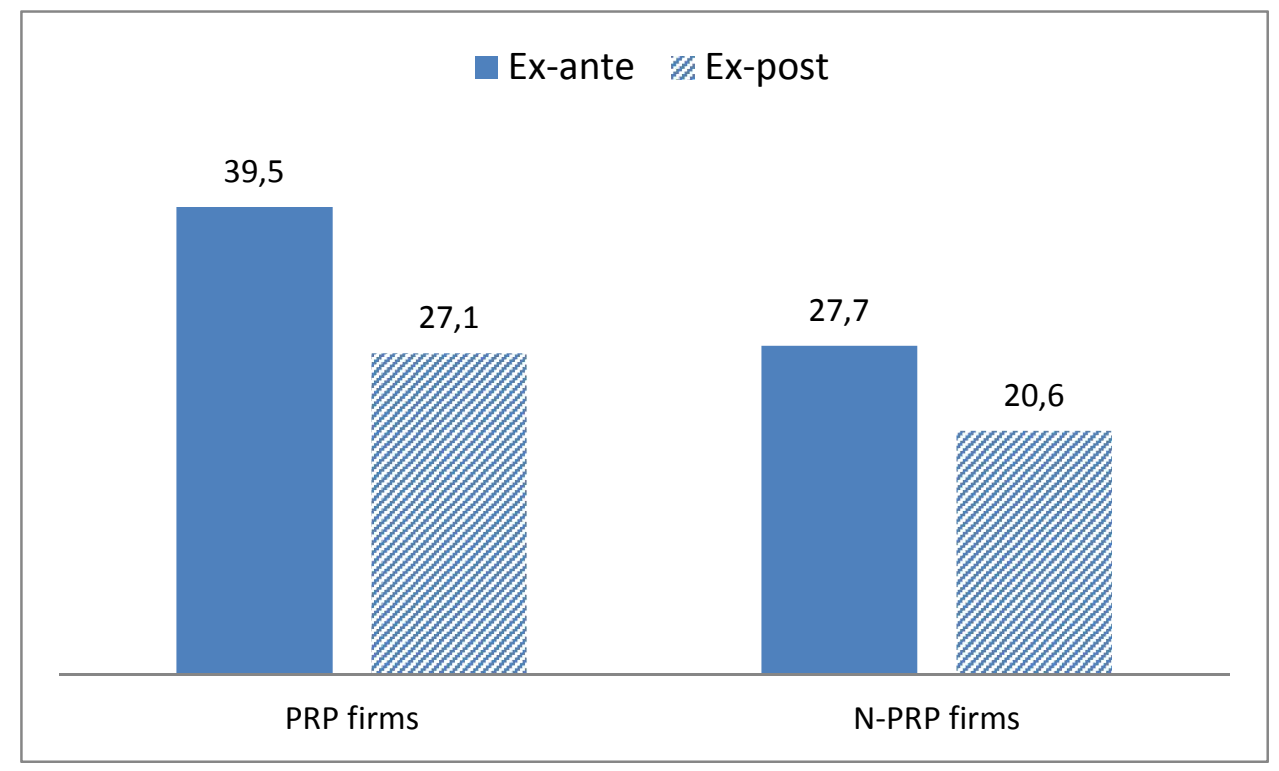

Figure 1 Wage differentials: comparison between PRP firms and N-PPR firms

Wage range between the maximum and minimum paid to section manager.

PRP firms are those that introduced PRP, N-PRP firms are those that did not introduce PRP. Exante denotes the designed differentials, and ex-post denotes the actual differentials

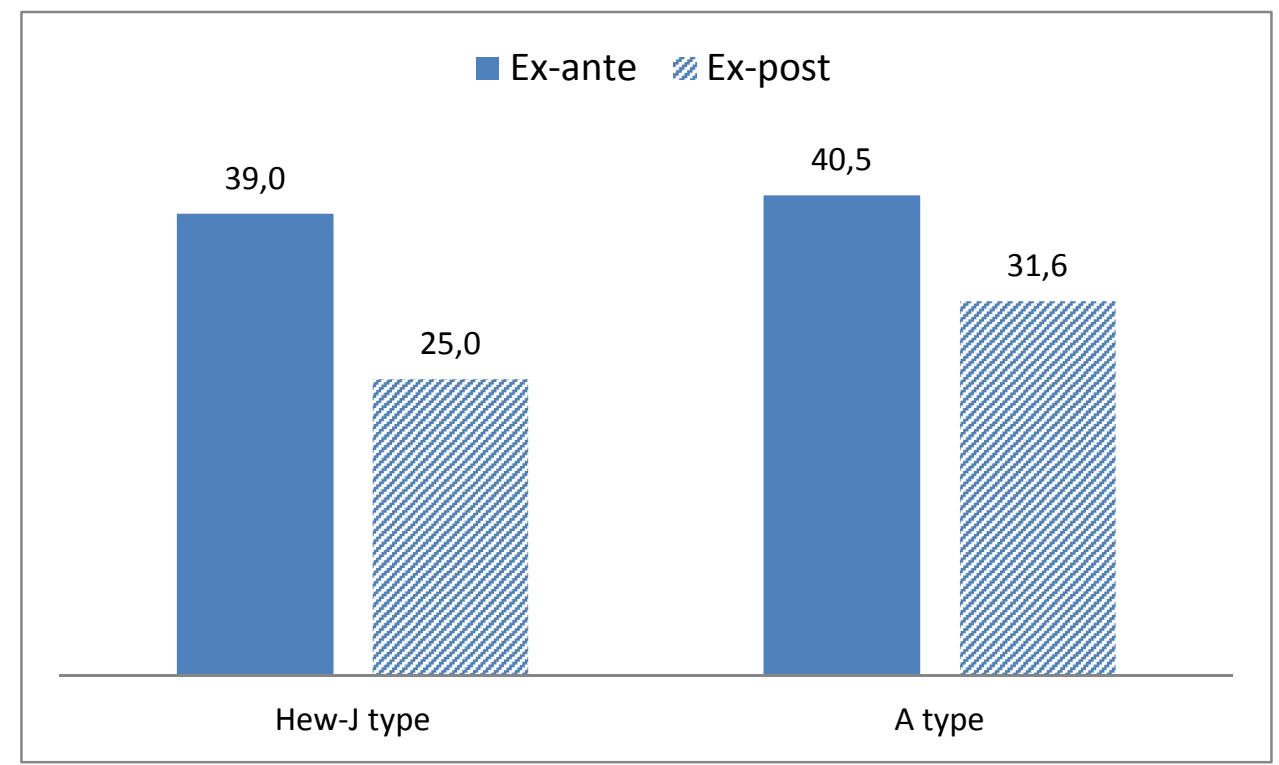

Figure 2 Wage differentials: comparison between new-J type and A type

New-J type denotes firms that introduced PRP and maintained LTE, A type denotes firms that introduced PRP, but did not maintain LTE. 
Table 1 Characteristics of respondents

\begin{tabular}{l|c|c}
\hline Gender (\%) & 2005 & 2009 \\
\hline Male & 79.7 & 90.9 \\
Female & 20.3 & 9.1 \\
\hline \multicolumn{3}{|l}{} \\
\hline Age group (\%) & 2005 & 2009 \\
\hline$<29$ & 18.4 & 4.3 \\
$30-39$ & 33.1 & 29.5 \\
$40-49$ & 27.9 & 45.1 \\
$50-59$ & 20.6 & 21.2 \\
\hline \multicolumn{3}{|l}{} \\
\hline Education (\%) & 2005 & 2009 \\
\hline High school & 22.9 & 13.3 \\
College & 13.6 & 11.7 \\
University & 63.5 & 75.0 \\
\hline
\end{tabular}

\begin{tabular}{l|c|c}
\hline Number of employees & 2005 & 2009 \\
\hline $100-300$ & 12.4 & 23.0 \\
$300-1000$ & 62.0 & 22.1 \\
$1000<$ & 25.6 & 54.9 \\
\hline \multicolumn{3}{|c}{} \\
\hline Post (\%) & 2005 & 2009 \\
\hline Division manager & 9.4 & 22.5 \\
Section manager & 25.0 & 29.1 \\
Team leader & 18.1 & 29.4 \\
No managers & 47.5 & 19.0 \\
\hline \multicolumn{3}{|c}{} \\
\hline Tenure (year) & 2005 & 2009 \\
\hline Mean & 14.6 & 16.5 \\
Median & 13 & 17 \\
\hline
\end{tabular}

Table 2 State of motivations (values are \%)

\begin{tabular}{l|c|c|c|c|c|c|c}
\hline \multirow{2}{*}{ Motivation type } & \multicolumn{3}{|c|}{ PRP employee } & \multicolumn{3}{c}{ N-PRP employee } \\
\cline { 3 - 8 } & & Increase & No change & Decrease & Increase & No change & Decrease \\
\hline Achieving individual & 2005 & 54.6 & 29.8 & 15.7 & 38.1 & 37.3 & 24.6 \\
performance & 2009 & 35.7 & 47.3 & 17.0 & 23.6 & 51.6 & 24.7 \\
\hline Contributing to & 2005 & 58.1 & 25.8 & 16.2 & 56.4 & 23.0 & 20.6 \\
company performance & 2009 & 39.7 & 43.7 & 16.6 & 35.7 & 48.2 & 16.1 \\
\hline Meeting a new & 2005 & 34.9 & 40.8 & 24.3 & 32.2 & 38.8 & 29.0 \\
challenge & 2009 & 22.6 & 49.8 & 27.7 & 17.9 & 54.0 & 28.1 \\
\hline
\end{tabular}

PRP employee denotes those who gave replies that PRP was introduced.

N-PRP employees denotes those who did not give replies that PRP was introduced. 


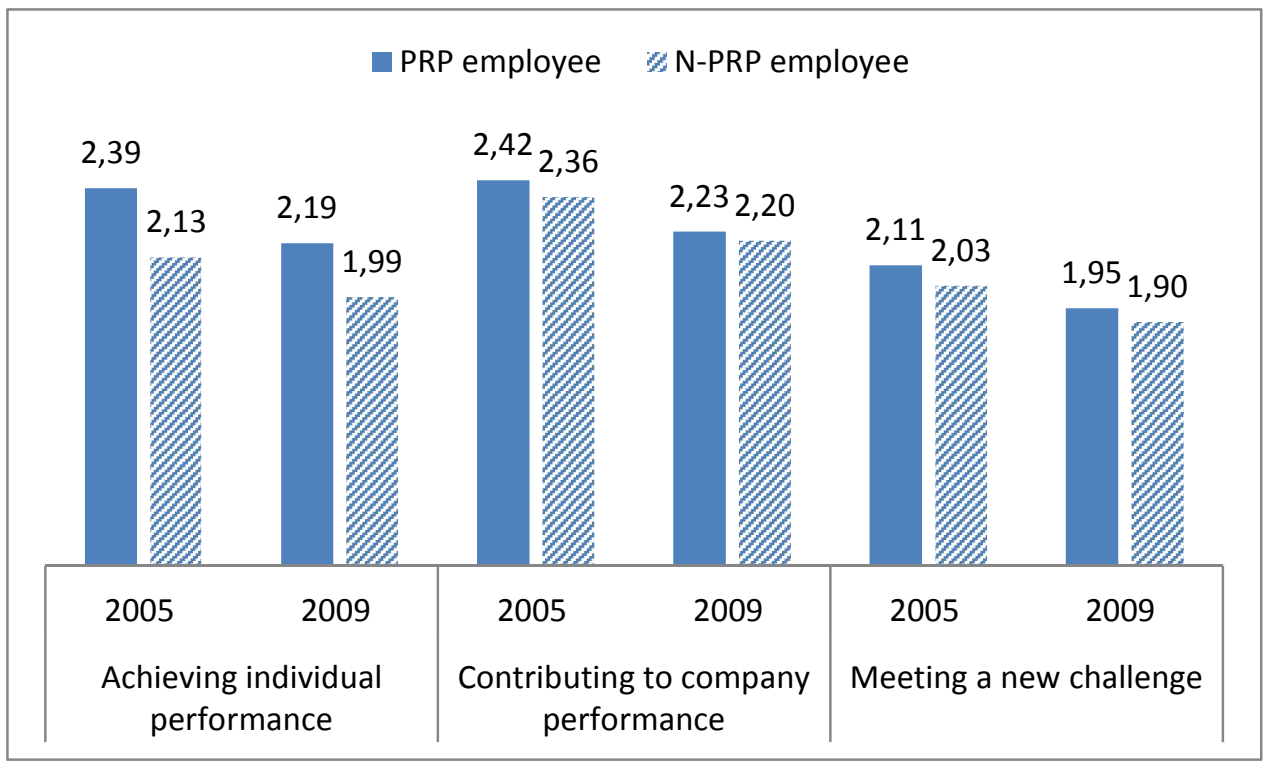

Figure3 Score of motivation

Table 3 Basic data

Percentage of replies to LTE and PRP

\begin{tabular}{c|c|c|c}
\hline & \multicolumn{2}{|c|}{ Employee survey } & Firm survey \\
\cline { 2 - 4 } & 2005 & 2009 & 2004 \\
\hline LTE is continued & 40.7 & 44.4 & 71.3 \\
\hline PRP is intriduced & 62.5 & 70.9 & 53.6 \\
\hline
\end{tabular}

Composition of wage (\%)

\begin{tabular}{l|l|c|l|l}
\hline \multicolumn{2}{l|}{} & $\begin{array}{l}\text { Seniority- } \\
\text { based }\end{array}$ & $\begin{array}{l}\text { Ability- } \\
\text { based }\end{array}$ & $\begin{array}{l}\text { Performance } \\
\text { based }\end{array}$ \\
\hline \multirow{2}{*}{2005} & PRP employees & 41.0 & 28.5 & 30.6 \\
& N-PRP employees & 50.8 & 25.5 & 23.8 \\
\hline 2009 & PRP employees & 39.5 & 28.2 & 32.3 \\
\hline
\end{tabular}

Wage variation (average range between good and bad results)

\begin{tabular}{l|l|ccccc}
\hline \multicolumn{2}{l|}{} & Average & S.D & Medium & Max & Min \\
\hline \multirow{2}{*}{2005} & PRP employees & 18.7 & 20.8 & 15 & 280 & 0 \\
& N-PRP employees & 17.7 & 20.3 & 12 & 220 & 0 \\
\hline 2009 & PRP employees & 20.8 & 20.1 & 20 & 275 & 0 \\
\hline
\end{tabular}

Horizontal differentials (wage gap between similar tenure)

\begin{tabular}{l|c|c|c|c|c|c}
\hline & \multicolumn{3}{|c|}{2005} & \multicolumn{3}{c}{2009} \\
\cline { 2 - 7 } & Widening & Contracting & Constant & Widening & Contracting & Constant \\
\hline PRP employees & 43.2 & 5.7 & 51.1 & 30.7 & 6.2 & 63.1 \\
N-PRP employees & 15.9 & 6.9 & 77.2 & 13.6 & 5.9 & 80.5 \\
\hline
\end{tabular}


Vertical differentials (wage gap between different tenure)

\begin{tabular}{l|c|c|c|c|c|c}
\hline & \multicolumn{3}{|c|}{2005} & \multicolumn{3}{c}{2009} \\
\cline { 2 - 7 } & Widening & Contracting & Constant & Widening & Contracting & Constant \\
\hline PRP employees & 23.8 & 24.1 & 52.2 & 25.2 & 10.8 & 64.0 \\
N-PRP employees & 11.5 & 15.2 & 73.3 & 13.8 & 8.0 & 78.3 \\
\hline
\end{tabular}


Table 4 Determinants of the motivation for achieving individual performance

\begin{tabular}{|c|c|c|c|c|c|c|c|c|}
\hline & \multicolumn{4}{|c|}{2005} & \multicolumn{4}{|c|}{2009} \\
\hline & $(1)$ & (2) & (3) & (4) & (1) & (2) & (3) & (4) \\
\hline PRP dummy & $\begin{array}{r}0.607 * * * \\
(7.40)\end{array}$ & & & & $\begin{array}{r}0.475 * * * \\
(8.46)\end{array}$ & & & \\
\hline Hybrid dummy & & $\begin{array}{r}0.477 * * * \\
(5.18)\end{array}$ & & & & $\begin{array}{r}0.280 * * * \\
(5.14)\end{array}$ & & \\
\hline Rate of PRP & & & $\begin{array}{r}1.447 * * * \\
(3.55)\end{array}$ & $\begin{array}{r}1.505 * * * \\
(3.65)\end{array}$ & & & $\begin{array}{r}0.621 * * * \\
(3.46)\end{array}$ & $\begin{array}{r}0.608 * * * \\
(3.35)\end{array}$ \\
\hline Wage variation & & & $\begin{array}{r}0.587 * * * \\
(3.49)\end{array}$ & $\begin{array}{r}0.583 * * * \\
(3.43)\end{array}$ & & & $\begin{array}{r}0.249 * * * \\
(3.00)\end{array}$ & $\begin{array}{l}0.213 * * \\
(2.54)\end{array}$ \\
\hline Square of variation & & & $\begin{array}{l}-0.134 * * * \\
(-2.93)\end{array}$ & $\begin{array}{l}-0.131 * * * \\
(-2.84)\end{array}$ & & & $\begin{array}{l}-0.0410 * \\
(-1.95)\end{array}$ & $\begin{array}{l}-0.031 \\
(-1.46)\end{array}$ \\
\hline $\begin{array}{l}\text { Horizontal differentials } \\
\text { (Widening dummy) }\end{array}$ & & & $\begin{array}{l}0.394 * * \\
(2.49)\end{array}$ & $\begin{array}{r}0.387 * * \\
(2.42)\end{array}$ & & & $\begin{array}{r}0.276 * * * \\
(3.05)\end{array}$ & $\begin{array}{r}0.292 * * * \\
(3.20)\end{array}$ \\
\hline $\begin{array}{l}\text { Horizontal differentials } \\
\text { (Contracting dummy) }\end{array}$ & & & $\begin{array}{l}0.174 \\
(0.59)\end{array}$ & $\begin{array}{l}0.179 \\
(0.61)\end{array}$ & & & $\begin{array}{l}0.185 \\
(1.28)\end{array}$ & $\begin{array}{l}0.204 \\
(1.39)\end{array}$ \\
\hline $\begin{array}{l}\text { Vertical differentials } \\
\text { (Widening dummy) }\end{array}$ & & & $\begin{array}{l}0.218 \\
(1.21)\end{array}$ & $\begin{array}{l}0.211 \\
(1.16)\end{array}$ & & & $\begin{array}{r}0.0856 \\
(0.89)\end{array}$ & $\begin{array}{r}0.0748 \\
(0.77)\end{array}$ \\
\hline $\begin{array}{l}\text { Vertical differentials } \\
\text { (Contracting dummy) }\end{array}$ & & & $\begin{array}{l}0.451 * * \\
(2.57)\end{array}$ & $\begin{array}{r}0.444 * * \\
(2.50)\end{array}$ & & & $\begin{array}{l}0.194 * \\
\quad(1.67)\end{array}$ & $\begin{array}{l}0.192 \\
(1.63)\end{array}$ \\
\hline LTE dummy & & & $\begin{array}{l}0.299 * * \\
(2.40)\end{array}$ & $\begin{array}{l}0.205 \\
(1.61)\end{array}$ & & & $\begin{array}{r}0.168 * * * \\
(2.64)\end{array}$ & $\begin{array}{r}0.0461 \\
(0.71)\end{array}$ \\
\hline Work satisfaction & & & & $\begin{array}{r}0.305 * * * \\
(4.89)\end{array}$ & & & & $\begin{array}{r}0.467 * * * \\
(13.19)\end{array}$ \\
\hline Manager dummy & $\begin{array}{r}0.310 * * * \\
(3.43)\end{array}$ & $\begin{array}{r}0.239 * * \\
(2.53)\end{array}$ & $\begin{array}{l}0.204 \\
(1.49)\end{array}$ & $\begin{array}{r}0.19 \\
(1.37)\end{array}$ & $\begin{array}{r}0.392 * * * \\
(7.80)\end{array}$ & $\begin{array}{r}0.351 * * * \\
(6.44)\end{array}$ & $\begin{array}{r}0.299 * * * \\
(4.50)\end{array}$ & $\begin{array}{r}0.189 * * * \\
(2.80)\end{array}$ \\
\hline Tenure & $\begin{array}{r}-0.056 \\
(-1.05)\end{array}$ & $\begin{array}{l}-0.0225 \\
(-0.39)\end{array}$ & $\begin{array}{l}-0.103 \\
(-0.99)\end{array}$ & $\begin{array}{l}-0.0771 \\
(-0.73)\end{array}$ & $\begin{array}{l}-0.0943 * * \\
(-2.83)\end{array}$ & $\begin{array}{l}-0.0770 * * \\
(-2.14)\end{array}$ & $\begin{array}{l}-0.136 * * * \\
(-2.77)\end{array}$ & $\begin{array}{l}-0.0961 * \\
(-1.93)\end{array}$ \\
\hline Employee dummy & $\begin{array}{l}0.119 \\
(1.32)\end{array}$ & $\begin{array}{r}0.227 * * \\
(2.41)\end{array}$ & $\begin{aligned} &-0.133 \\
&(-1.02)\end{aligned}$ & $\begin{array}{r}-0.179 \\
(-1.36)\end{array}$ & $\begin{array}{r}0.159 * * * \\
(3.14)\end{array}$ & $\begin{array}{r}0.202 * * * \\
(3.71)\end{array}$ & $\begin{array}{l}0.117 * \\
\quad(1.76)\end{array}$ & $\begin{array}{c}0.102 \\
(1.52)\end{array}$ \\
\hline Industry dummy & $\begin{array}{r}0.167 * * \\
(2.09)\end{array}$ & $\begin{array}{l}0.139 \\
(1.64)\end{array}$ & $\begin{array}{l}0.138 \\
(1.11)\end{array}$ & $\begin{array}{l}0.117 \\
(0.93)\end{array}$ & $\begin{array}{r}0.0498 \\
(1.02)\end{array}$ & $\begin{array}{r}0.0551 \\
(1.04)\end{array}$ & $\begin{array}{l}0.059 \\
(0.94)\end{array}$ & $\begin{array}{r}0.0588 \\
(0.93)\end{array}$ \\
\hline Mumber of observations & 2369 & 2085 & 1070 & 1062 & 6317 & 5303 & 3762 & 3762 \\
\hline Log Likelihood & -2401.51 & -2109.33 & -993.936 & -974.964 & -6435.53 & -5470.33 & -3802.67 & -3713.44 \\
\hline Pseudo R2 & 0.017 & 0.0111 & 0.0348 & 0.0464 & 0.0134 & 0.0084 & 0.0138 & 0.037 \\
\hline
\end{tabular}


Marginal effects on increase of motivation for individual performance

\begin{tabular}{l|ll|ll}
\hline & \multicolumn{2}{|c|}{2005} & \multicolumn{2}{c}{2009} \\
\hline Rate of PRP & $0.334 * * *$ & $0.340 * * *$ & $0.143 * * *$ & $0.135 * * *$ \\
Wage variation & $0.135 * * *$ & $0.132 * * *$ & $0.058 * * *$ & $0.047 * *$ \\
Horizontal differentials(Widening) & $0.091 * *$ & $0.087 * *$ & $0.064 * * *$ & $0.065 * * *$ \\
Horizontal differentials(Contracting) & 0.040 & 0.040 & 0.043 & 0.045 \\
Vertical differentials(Widening) & 0.050 & 0.048 & 0.020 & 0.017 \\
Vertical differentials(Contracting) & $0.104 * *$ & $0.100 * *$ & $0.045 *$ & 0.043 \\
LTE dummy & $0.069 * *$ & 0.046 & $0.039 * * *$ & 0.010 \\
Work motivation & & $0.069 * * *$ & & $0.104 * * *$ \\
\hline
\end{tabular}


Table 5 Determinants of the motivation for contributing to overall company performance

\begin{tabular}{|c|c|c|c|c|c|c|c|c|}
\hline & \multicolumn{4}{|c|}{2005} & \multicolumn{4}{|c|}{2009} \\
\hline & (1) & (2) & (3) & (4) & (1) & (2) & (3) & (4) \\
\hline PRP dummy & $\begin{array}{r}0.0708 \\
(0.83)\end{array}$ & & & & $\begin{array}{r}0.0283 \\
(0.51)\end{array}$ & & & \\
\hline Hybrid dummy & & $\begin{array}{r}0.232 * * \\
(2.45)\end{array}$ & & & & $\begin{array}{r}0.281 * * * \\
(5.16)\end{array}$ & & \\
\hline Rate of PRP & & & $\begin{array}{r}1.200 * * * \\
(2.93)\end{array}$ & $\begin{array}{r}1.204 * * * \\
(2.93)\end{array}$ & & & $\begin{array}{r}0.24 \\
(1.33)\end{array}$ & $\begin{array}{l}0.197 \\
(1.09)\end{array}$ \\
\hline Wage variation & & & $\begin{array}{r}0.432 * * \\
(2.56)\end{array}$ & $\begin{array}{r}0.429 * * \\
(2.53)\end{array}$ & & & $\begin{array}{r}0.274 * * * \\
(3.29)\end{array}$ & $\begin{array}{r}0.246 * * * \\
(2.93)\end{array}$ \\
\hline Square of variation & & & $\begin{array}{l}-0.0893 * \\
(-1.95)\end{array}$ & $\begin{array}{l}-0.0882 * \\
(-1.92)\end{array}$ & & & $\begin{array}{l}-0.0553 * * \\
(-2.62)\end{array}$ & $\begin{array}{l}-0.0471 * * \\
(-2.22)\end{array}$ \\
\hline $\begin{array}{l}\text { Horizontal differentials } \\
\text { (Widening dummy) }\end{array}$ & & & $\begin{array}{r}0.353 * * \\
(2.25)\end{array}$ & $\begin{array}{r}0.360 * * \\
(2.29)\end{array}$ & & & $\begin{array}{l}0.229 * * \\
\quad(2.54)\end{array}$ & $\begin{array}{r}0.240 * * * \\
(2.64)\end{array}$ \\
\hline $\begin{array}{l}\text { Horizontal differentials } \\
\text { (Contracting dummy) }\end{array}$ & & & $\begin{array}{l}0.337 \\
(1.09)\end{array}$ & $\begin{array}{l}0.361 \\
(1.17)\end{array}$ & & & $\begin{array}{l}0.163 \\
(1.12)\end{array}$ & $\begin{array}{l}0.165 \\
(1.12)\end{array}$ \\
\hline $\begin{array}{l}\text { Vertical differentials } \\
\text { (Widening dummy) }\end{array}$ & & & $\begin{array}{l}0.189 \\
(1.04)\end{array}$ & $\begin{array}{l}0.201 \\
(1.10)\end{array}$ & & & $\begin{array}{r}0.00504 \\
(0.05)\end{array}$ & $\begin{array}{l}-0.0105 \\
(-0.11)\end{array}$ \\
\hline $\begin{array}{l}\text { Vertical differentials } \\
\quad \text { (Contracting dummy) }\end{array}$ & & & $\begin{array}{r}0.0208 \\
(0.12)\end{array}$ & $\begin{array}{l}0.024 \\
(0.14)\end{array}$ & & & $\begin{array}{l}0.171 \\
(1.47)\end{array}$ & $\begin{array}{l}0.171 \\
(1.45)\end{array}$ \\
\hline LTE dummy & & & $\begin{array}{r}0.449 * * * \\
(3.56)\end{array}$ & $\begin{array}{r}0.396 * * * \\
(3.10)\end{array}$ & & & $\begin{array}{r}0.382 * * * \\
(6.02)\end{array}$ & $\begin{array}{r}0.283 * * * \\
(4.38)\end{array}$ \\
\hline Work satisfaction & & & & $\begin{array}{r}0.206 * * * \\
(3.33)\end{array}$ & & & & $\begin{array}{r}0.390 * * * \\
\quad(11.20)\end{array}$ \\
\hline Manager dummy & $\begin{array}{r}0.300 * * * \\
(3.22)\end{array}$ & $\begin{array}{l}0.243 * * \\
(2.47)\end{array}$ & $\begin{array}{l}0.222 \\
(1.61)\end{array}$ & $\begin{array}{l}0.208 \\
(1.50)\end{array}$ & $\begin{array}{r}0.236 * * * \\
(4.73)\end{array}$ & $\begin{array}{r}0.183 * * * \\
(3.36)\end{array}$ & $\begin{array}{r}0.222 * * * \\
(3.34)\end{array}$ & $\begin{array}{l}0.127 * \\
\quad(1.89)\end{array}$ \\
\hline Tenure & $\begin{array}{r}0.0393 \\
(0.72)\end{array}$ & $\begin{array}{r}0.0493 \\
(0.82)\end{array}$ & $\begin{array}{r}0.0748 \\
(0.73)\end{array}$ & $\begin{array}{r}0.0767 \\
(0.74)\end{array}$ & $\begin{array}{l}-0.00657 \\
(-0.20)\end{array}$ & $\begin{array}{l}-0.0112 \\
(-0.31)\end{array}$ & $\begin{array}{l}-0.0617 \\
(-1.27)\end{array}$ & $\begin{array}{l}-0.0279 \\
(-0.57)\end{array}$ \\
\hline Employee dummy & $\begin{array}{r}0.197 * * \\
(2.10)\end{array}$ & $\begin{array}{r}0.145 \\
(1.48)\end{array}$ & $\begin{array}{r}0.202 \\
(1.52)\end{array}$ & $\begin{array}{l}0.176 \\
(1.32)\end{array}$ & $\begin{array}{l}0.102 * * \\
\quad(2.03)\end{array}$ & $\begin{array}{r}0.0397 \\
(0.73)\end{array}$ & $\begin{array}{r}0.0143 \\
(0.22)\end{array}$ & $\begin{array}{l}-0.00455 \\
(-0.07)\end{array}$ \\
\hline Industry dummy & $\begin{array}{r}0.0224 \\
(0.27)\end{array}$ & $\begin{array}{l}-0.0228 \\
(-0.26)\end{array}$ & $\begin{array}{l}-0.108 \\
(-0.87)\end{array}$ & $\begin{array}{c}-0.103 \\
(-0.82)\end{array}$ & $\begin{array}{r}0.101 * * \\
\quad(2.07)\end{array}$ & $\begin{array}{l}0.111 * * \\
(2.10)\end{array}$ & $\begin{array}{l}0.154 * * \\
\quad(2.45)\end{array}$ & $\begin{array}{r}0.156 * * \\
(2.46)\end{array}$ \\
\hline Mumber of observations & 2370 & 2087 & 1072 & 1064 & 6313 & 5300 & 3757 & 3757 \\
\hline Log Likelihood & -2284.82 & -1980.97 & -988.792 & -979.194 & -6447.64 & -5421.3 & -3811.03 & -3747.21 \\
\hline Pseudo R2 & 0.0049 & 0.0051 & 0.0308 & 0.0362 & 0.0026 & 0.0046 & 0.0114 & 0.028 \\
\hline
\end{tabular}


Marginal effects on increase of motivation for company's performance

\begin{tabular}{l|ll|lc}
\hline & \multicolumn{2}{|c|}{2005} & \multicolumn{2}{c}{2009} \\
\hline Rate of PRP & $0.275 * * *$ & $0.274 * * *$ & 0.057 & 0.046 \\
Wage variation & $0.099 * *$ & $0.098 * *$ & $0.066 * * *$ & $0.057 * * *$ \\
Horizontal differentials(Widening) & $0.081 * *$ & $0.082 * *$ & $0.055 * *$ & $0.056 * * *$ \\
Horizontal differentials(Contracting) & 0.077 & 0.082 & 0.039 & 0.038 \\
Vertical differentials(Widening) & 0.043 & 0.046 & 0.001 & -0.002 \\
Vertical differentials(Contracting) & 0.005 & 0.005 & 0.041 & 0.040 \\
LTE dummy & $0.103 * * *$ & $0.090 * * *$ & $0.091 * * *$ & $0.066 * * *$ \\
Work motivation & & $0.047 * * *$ & & $0.091 * * *$ \\
\hline
\end{tabular}


Table 6 Determinants of the motivation for meeting a new challenge

\begin{tabular}{|c|c|c|c|c|c|c|c|c|}
\hline & \multicolumn{4}{|c|}{2005} & \multicolumn{4}{|c|}{2009} \\
\hline & (1) & (2) & (3) & $(4)$ & $(1)$ & (2) & (3) & $(4)$ \\
\hline PRP dummy & $\begin{array}{l}0.157 * \\
(1.94)\end{array}$ & & & & $\begin{array}{r}0.0834 \\
(1.50)\end{array}$ & & & \\
\hline Hybrid dummy & & $\begin{array}{r}0.458 * * * \\
(5.16)\end{array}$ & & & & $\begin{array}{r}0.436 * * * \\
(7.97)\end{array}$ & & \\
\hline Rate of PRP & & & $\begin{array}{r}1.133 * * * \\
(3.00)\end{array}$ & $\begin{array}{r}1.150 * * * \\
(3.00)\end{array}$ & & & $\begin{array}{l}0.109 \\
(0.61)\end{array}$ & $\begin{array}{r}0.0327 \\
-0.18\end{array}$ \\
\hline Wage variation & & & $\begin{array}{l}0.146 \\
(0.92)\end{array}$ & $\begin{array}{l}0.145 \\
(0.90)\end{array}$ & & & $\begin{array}{r}0.208 * * \\
(2.50)\end{array}$ & $\begin{array}{l}0.146 * \\
\quad(1.72)\end{array}$ \\
\hline Square of variation & & & $\begin{array}{l}-0.0249 \\
(-0.58)\end{array}$ & $\begin{array}{l}-0.0195 \\
(-0.45)\end{array}$ & & & $\begin{array}{l}-0.0305 \\
(-1.45)\end{array}$ & $\begin{array}{l}-0.0134 \\
(-0.62)\end{array}$ \\
\hline $\begin{array}{l}\text { Horizontal differentials } \\
\text { (Widening dummy) }\end{array}$ & & & $\begin{array}{l}0.291 * * \\
\quad(1.97)\end{array}$ & $\begin{array}{l}0.284 * \\
\quad(1.90)\end{array}$ & & & $\begin{array}{r}0.0272 \\
(0.30)\end{array}$ & $\begin{array}{r}0.0484 \\
(0.53)\end{array}$ \\
\hline $\begin{array}{l}\text { Horizontal differentials } \\
\text { (Contracting dummy) }\end{array}$ & & & $\begin{array}{l}0.345 \\
(1.27)\end{array}$ & $\begin{array}{l}0.386 \\
(1.40)\end{array}$ & & & $\begin{array}{r}0.381 * * * \\
(2.65)\end{array}$ & $\begin{array}{r}0.426 * * * \\
(2.93)\end{array}$ \\
\hline $\begin{array}{l}\text { Vertical differentials } \\
\text { (Widening dummy) }\end{array}$ & & & $\begin{array}{l}-0.198 \\
(-1.19)\end{array}$ & $\begin{array}{l}-0.196 \\
(-1.17)\end{array}$ & & & $\begin{array}{l}-0.0101 \\
(-0.11)\end{array}$ & $\begin{array}{l}-0.0226 \\
(-0.23)\end{array}$ \\
\hline $\begin{array}{l}\text { Vertical differentials } \\
\text { (Contracting dummy) }\end{array}$ & & & $\begin{array}{r}0.0947 \\
(0.58)\end{array}$ & $\begin{array}{r}0.0868 \\
(0.52)\end{array}$ & & & $\begin{array}{l}-0.0619 \\
(-0.54)\end{array}$ & $\begin{array}{l}-0.052 \\
(-0.45)\end{array}$ \\
\hline LTE dummy & & & $\begin{array}{r}0.556 * * * \\
(4.75)\end{array}$ & $\begin{array}{r}0.435 * * * \\
(3.65)\end{array}$ & & & $\begin{array}{r}0.528 * * * \\
(8.29)\end{array}$ & $\begin{array}{r}0.375 * * * \\
\quad(5.76)\end{array}$ \\
\hline Work satisfaction & & & & $\begin{array}{r}0.494 * * * \\
(8.15)\end{array}$ & & & & $\begin{array}{l}0.655 * * * \\
\quad(18.01)\end{array}$ \\
\hline Manager dummy & $\begin{array}{l}0.165 * \\
(1.89)\end{array}$ & $\begin{array}{r}0.0832 \\
(0.91)\end{array}$ & $\begin{array}{l}0.163 \\
(1.28)\end{array}$ & $\begin{array}{r}0.13 \\
(1.01)\end{array}$ & $\begin{array}{r}0.422 * * * \\
(8.36)\end{array}$ & $\begin{array}{r}0.386 * * * \\
(7.06)\end{array}$ & $\begin{array}{r}0.414 * * * \\
(6.23)\end{array}$ & $\begin{array}{r}0.273 * * * \\
(4.03)\end{array}$ \\
\hline Tenure & $\begin{array}{c}-0.0744 \\
(-1.45)\end{array}$ & $\begin{array}{l}-0.0319 \\
(-0.57)\end{array}$ & $\begin{array}{l}-0.133 \\
(-1.37)\end{array}$ & $\begin{array}{l}-0.105 \\
(-1.06)\end{array}$ & $\begin{array}{l}-0.169 * * * \\
(-5.01)\end{array}$ & $\begin{array}{c}k-0.204 * * * \\
(-5.60)\end{array}$ & $\begin{array}{l}-0.242 * * * \\
(-4.92)\end{array}$ & $\begin{array}{l}-0.194 * * * \\
(-3.89)\end{array}$ \\
\hline Employee dummy & $\begin{array}{l}0.115 \\
(1.32)\end{array}$ & $\begin{array}{l}0.117 \\
(1.28)\end{array}$ & $\begin{array}{l}-0.045 \\
(-0.37)\end{array}$ & $\begin{array}{l}-0.12 \\
(-0.97)\end{array}$ & $\begin{array}{r}0.167 * * * \\
(3.29)\end{array}$ & $\begin{array}{l}0.106 * \\
(1.94)\end{array}$ & $\begin{array}{r}0.0861 \\
(1.30)\end{array}$ & $\begin{array}{r}0.0576 \\
(0.86)\end{array}$ \\
\hline Industry dummy & $\begin{array}{r}0.144 * \\
\quad(1.86)\end{array}$ & $\begin{array}{r}0.12 \\
(1.45)\end{array}$ & $\begin{array}{l}0.222 * \\
\quad(1.91)\end{array}$ & $\begin{array}{l}0.219 * \\
\quad(1.86)\end{array}$ & $\begin{array}{r}0.0222 \\
(0.45)\end{array}$ & $\begin{array}{r}0.0104 \\
(0.20)\end{array}$ & $\begin{array}{r}0.0291 \\
(0.46)\end{array}$ & $\begin{array}{r}0.0391 \\
(0.61)\end{array}$ \\
\hline Mumber of observations & 2365 & 2084 & 1077 & 1069 & 6314 & 5298 & 3755 & 3755 \\
\hline Log Likelihood & -2556.01 & -2240.64 & -1138.04 & -1095.04 & -6450.81 & -5492.03 & -3881.89 & -3710.24 \\
\hline Pseudo R2 & 0.0029 & 0.0076 & 0.0211 & 0.0513 & 0.0069 & 0.0119 & 0.0176 & 0.061 \\
\hline
\end{tabular}


Marginal effects on increase of motivation for a new challenge

\begin{tabular}{l|ll|ll}
\hline & \multicolumn{2}{|c|}{2005} & \multicolumn{2}{c}{2009} \\
\hline Rate of PRP & $0.252 * * *$ & $0.243 * * *$ & 0.020 & 0.006 \\
Wage variation & 0.032 & 0.031 & $0.037 * *$ & $0.025 *$ \\
Horizontal differentials(Widening) & $0.065 * *$ & $0.060 *$ & 0.005 & 0.008 \\
Horizontal differentials(Contracting) & 0.077 & 0.082 & $0.068 * * *$ & $0.073 * * *$ \\
Vertical differentials(Widening) & -0.044 & -0.042 & -0.002 & -0.004 \\
Vertical differentials(Contracting) & 0.021 & 0.018 & -0.011 & -0.009 \\
LTE dummy & $0.124 * * *$ & $0.092 * * *$ & $0.095 * * *$ & $0.064 * * *$ \\
Work motivation & & $0.104 * * *$ & & $0.112 * * *$ \\
\hline
\end{tabular}

